\title{
In vitro biology of Columbicola bacillus (Phthiraptera: Ischnocera)
}

\author{
Padam Singh, Gaurav Arya, A ftab A hmad and A .K . Saxena* \\ Department of Zoology, Government Raza Postgraduate College, Rampur - 244901 (U.P.), INDIA \\ *Correspondending author. E-mail: akscsir@ rediffmail.com \\ Received: J une 18, 2012; Revised received: J uly 28, 2012; Accepted:September 26,2012
}

Abstract: An ischnoceran louse, Columbicola bacillus infesting Ring dove, Streptopelia decaocto was subjected to in vitro experimentation. The data obtained through in vitro experimentation was utilized to construct the life table and to determine its intrinsic rate of natural increase $(\mathrm{rm})$. The value of $\mathrm{rm}$ appeared to be 0.054 . At this rate, the population of $\mathrm{C}$. bacillus is supposed to be double after 12.95 days, indicating that it is moderate breeder.

Keywords: Intrinsic rate, Ischnocera, Life table, Phthiraptera, Population expansion

\section{INTRODUCTION}

Population growth rate of any organism depends upon its reproductive potential and the length of the generation. A look on literature reveals that the reproductive potentials of phthirapteran species reportedly differ considerably. Some species may be considered fast breeder than the others (arbitrarily). The value of the intrinsic rate of natural increase (rate of increase per head in a population which has attained a stable age distribution; denoted by $\mathrm{rm}$ ) of any organism provides vital clues regarding its rate of population expansion. During last few years some workers have tried to compute the intrinsic rate of natural increase of selected species on the basis of data obtained through in vitro experimentation (Saxena et al., 2007, 2009; Gupta et al., 2007, Arya et al., 2009). Intrinsic rate of natural increase of two mammalian ischnoceran have also been indicated (Murray and Gordon, 1969; Rust, 1974). Since the values of rm of the species studied so far, varied considerably, it was found worthwhile to determine the life table statistics of one more ischnoceran louse. Moreover, the rm of any Eurasian Collered Dove lice has yet not been investigated. In the present paper an attempt has been made to compute the intrinsic rate of natural increase of Columbicola bacillus infesting Eurasian Collered Dove (Streptopelia decaocto) (Frivaldszky, 1838), on the basis of data obtained through in vitro experimentation on the aforesaid lice.

\section{MATERIALS AND METHODS}

Eurasian Collered Dove were trapped alive (during 20102011, in district Rampur,U.P.) and subjected to delousing (manually). Few feathers were gently taken out amd the deloused bird released in wild. Feathers bearing fresh eggs of $\mathrm{C}$. bacillus were gently cut from the host body and incubated in culture vials (at $35 \pm 1^{\circ} \mathrm{C}, 75-82 \% \mathrm{RH}$ ), to record the incubation period. Freshly emerged nymphal instars were reared on the host feather diet, to determine the duration of three nymphal instars. Likewise, the colonies of apparently freshly moulted healthier adult lice were reared in vitro condition (in batches) to determine the adult longevity Culture vials were examined daily. The construction of the life table and computation of value of $\mathrm{rm}\left(\sum \mathrm{e}^{-\mathrm{rmx}} \mathrm{lxmx}=1\right.$; where $\mathrm{e}=$ base of natural logarithms; $\mathrm{x}=$ age of individuals in days; $1 \mathrm{x}=$ number of individuals alive at age $\mathrm{x}$ as a proportion of one; $\mathrm{mx}=$ number of female offsprings produced/ female in the age interval $x)$, net reproductive rate $\left(\mathrm{Ro}=\sum \mathrm{lxmx}\right)$, the innate capacity of increase $(\mathrm{rc}=\operatorname{logeRo} / \mathrm{Tc})$, the precise generation time $(\mathrm{T}=\operatorname{loge} \mathrm{Ro} / \mathrm{rm})$, the finite rate of increase $\left(\lambda=\mathrm{e}^{\mathrm{rm}}\right)$ and the doubling time of population (DT $=\log 2 /$ $\log \lambda$ ) was based on the method given by Birch (1948), Leslie and Park (1949), Evans and Smith (1952), Howe (1953) and also followed by Saxena et al. (2007, 2009), Gupta et al. (2007) and Arya et al. (2009).

\section{RESULTS AND DISCUSSION}

The results relating to in vitro rearing on $C$. bacillus have been presented in Table 1. The life table (Table 2) was constructed following the lines suggested by the aforesaid workers. In a separate study by authors (communicated elsewhere) relating to population composition, the male/ female ratio in natural population of $\mathrm{C}$. bacillus was recorded as 1:1.3. Hence, the maternal frequency $(\mathrm{mx}$, the average number of female eggs produced) was computed by multiplying the daily average egg rate by a factor of 0.52 . In Table 2 , the lx function indicates the probability of birth of a female being alive at age $X$, when lo is taken as unity. It may be noted that, while preparing the survivorship table, it was presumed that all the eggs laid were fertile and the nymph mortality on the host (in vivo) would be negligible. Few more vital 
Tablel. In vitro bionomics of $\mathrm{C}$. bacillus reared at $35 \pm 1^{\circ} \mathrm{C}, 75-82 \% \mathrm{RH}$, at feather diet.

$\begin{array}{lc}\text { Adult life span (male) } & 13.27 \pm 6.11 \text { days }(2-26 \text { days, } \mathrm{n}=150) \\ \text { Adult life span (female) } & 15.53 \pm 8.61 \text { days }(2-32 \text { days, } \mathrm{n}=150) \\ \text { Total number of egg produced } & 1894 \\ \text { Egg produced during life span } & 12.63 \\ \text { (egg laid / female during life span) } & 0.52 \\ \text { Egg rate / female /day } & 4.17 \pm 0.98 \text { days (range: } 4-7 \text { days, } \mathrm{n}=178) \\ \text { Incubation period } & 5.10 \pm 1.06 \text { days (range: } 4-8 \text { days, } \mathrm{n}=124) \\ \text { Duration of I nymphal instar } & 5.30 \pm 1.03 \text { days (range: } 4-7 \text { days, } \mathrm{n}=94) \\ \text { Duration of II nymphal instar } & 6.01 \pm 0.84 \text { days (range: } 4-7 \text { days, } \mathrm{n}=76) \\ \text { Duration of III nymphal instar } & 6.20 \\ \text { Net reproductive rate } & 12.37 \\ \text { Gross reproductive rate } & 35.93 \text { days } \\ \text { Mean length of generation } & 1.055 \\ \text { Finite rate of increase } & 33.79 \text { days } \\ \text { Precise generation time } & 1.055 \\ \text { Finite rate of increase } & \end{array}$

statistics of the louse have been indicated in the Table 1. The rm of the louse was computed by using the trial values to find the value which satisfied the equation $\Sigma \mathrm{e}^{-}$ ${ }^{r m x} \operatorname{lxmx}=1$. In Table 2 when $\mathrm{rm}=0.054$, the summation of $\mathrm{e}^{-\mathrm{rm} x} \operatorname{lxmx}$ for each age (in which $\mathrm{mx}>0$ ) appeared to be 1.006. At this rate $(\mathrm{rm}=0.54)$ the population of $\mathrm{C}$. bacillus is supposed to double after 12.95 days.

The scrutiny of literature shows that the intrinsic rate of natural increase of eight ischnoceran species e.g. $\mathrm{G}$ oniocotes gallinae (infesting the domestic fowl, $\mathrm{G}$ all us gallus domesticus), Brueelia amandavae (occurring on Red avadavat, Amandava amandava), B. cyclothorax (parasitizing house sparrow, Passer domesticus), Sturnidoecus bannoo (parasitizing common Myna, Acridotheres tristis), Neopsittaconirmus elbeli (infesting Indian parakeet, Psittacula eupatria), Columbicola columbae (occurring on domestic pigeon, Columba livia), A naticola crassicornis (parasitizing Mallard duck, Anas platyrhynchos) and Brueelia plocea ( infesting Common baya, Ploceus philippinus) have been recorded, so far (Saxena et al., 2007, 2009; Gupta et al., 2007; Arya et al. 2009). The values of intrinsic rate of natural increase of the aforesaid species have been recorded as $0.07,0.031$, $0.032,0.049,0.050,0.053,0.074$ and 0.045 . Likewise, the doubling time $(10.63,23.45,21.35,14.21,13.93,14.2,9.0$ and 15.41) of aforesaid species also exhibited considerable variations. In comparison to earlier studies species, the Ring dove louse, C. bacillus appears to be moderate breeder as its rm equaled 0.054 and the doubling time remained 12.95 days. Presumably, the fast breeding species may build their population at faster rate (than moderate and slow breeders) and consequently may cause extensive damage to feathers of the host. On the other hand, slow breeders may exhibit low prevalence and intensity of infestation and thus causing minimal effect on host plumage. The moderate breeders like $\mathrm{C}$. bacillus presumably are supposed to exhibit intermediate condition in this regard.

\section{ACKNOLEDGEMENTS}

The author are indebted to the Principal, Govt. Raza P. G. College, Rampur (U.P) for providing laboratory facilities, to Chief Wild Life Warden of U.P. (India) for permission to catch the birds and to the UGC, New Delhi for providing financial support to Dr. A. K. Saxena, in the form of project no. 38-86/2009 (SR).

\section{REFERENCES}

Arya, G., Ahmad, A., Bansal, N., Rashmi, A. and Saxena, A.K. (2009). Population expansion of the Common baya louse, Brueelia plocea (Lakhsminarayana, 1968) (Phthiraptera: Ischnocera). Rev. Ibero-Latinoam. Parasitol. 68(2): 192-195.

Birch, L.C. (1948). The intrinsic rate of natural increase of an insect population. I. Anim. Ecol., 17: 15-26.

Evans, F.C. and Smith F.E. (1952). The intrinsic rate of natural increase for the human louse, Pediculus humanus. L. The Amer. Nat., 86 (830): 299-310.

Gupta, N., Kumar S. and Saxena A. K. (2007). Intrinsic rate of natural increase of Brueelia amandavae (Ischnocera, Phthiraptera) infesting Indian Red Avadavat. Biologia., 62(4): 458-461.

Howe, R.W. (1953). The rapid determination of the intrinsic rate of increase of an insect population. Ann. Appl. Biol., 40 (1): 134-151.

Leslie, P.H. and Park T. (1949). The intrinsic rate of natural increase of Tribolium castaneum Herbst. E cology, 30: 469477.

Murray, M.D. and Gordon, G. (1969). Ecology of lice on sheep. VII: Population dynamics of D amalinia ovis (Schrank). Aust J. Zool., 17: 179-186.

Rust, R. W. (1974). The population dynamics and host 
Table 2. Lifetable, fecundity and rate of increase of $\mathrm{C}$. bacillus.

\begin{tabular}{|c|c|c|c|c|c|c|c|}
\hline$X$ & Ix & $\mathrm{mx}$ & Ixmx & $\mathrm{XIxmx}$ & $\mathrm{rmx}$ & $e^{r m x}$ & $\sum e^{r m x} \mid x m x$ \\
\hline $0-21$ & \multicolumn{7}{|c|}{ Immature stage of $C$. bacillus } \\
\hline $22-24$ & \multicolumn{7}{|c|}{ Pre-oviposition period } \\
\hline 25.0 & 1.00 & 0.00 & 0.00 & 0.00 & 1.350 & 0.26 & 0.000 \\
\hline 26.0 & 0.97 & 0.04 & 0.03 & 0.90 & 1.440 & 0.246 & 0.009 \\
\hline 27.0 & 0.92 & 0.14 & 0.12 & 3.37 & 1.458 & 0.233 & 0.029 \\
\hline 28.0 & 0.89 & 0.23 & 0.21 & 5.82 & 1.512 & 0.22 & 0.046 \\
\hline 29.0 & 0.85 & 0.30 & 0.26 & 7.44 & 1.566 & 0.209 & 0.054 \\
\hline 30.0 & 0.84 & 0.67 & 0.56 & 16.85 & 1.620 & 0.198 & 0.111 \\
\hline 31.0 & 0.78 & 0.70 & 0.55 & 16.98 & 1.674 & 0.187 & 0.103 \\
\hline 32.0 & 0.75 & 0.82 & 0.61 & 19.52 & 1.728 & 0.178 & 0.108 \\
\hline 33.0 & 0.71 & 0.78 & 0.55 & 18.08 & 1.782 & 0.168 & 0.092 \\
\hline 34.0 & 0.69 & 0.71 & 0.49 & 16.50 & 1.836 & 0.159 & 0.077 \\
\hline 35.0 & 0.63 & 0.64 & 0.40 & 14.07 & 1.890 & 0.151 & 0.061 \\
\hline 36.0 & 0.55 & 0.64 & 0.35 & 12.73 & 1.944 & 0.143 & 0.051 \\
\hline 37.0 & 0.53 & 0.66 & 0.35 & 12.83 & 1.998 & 0.136 & 0.047 \\
\hline 38.0 & 0.49 & 0.66 & 0.32 & 12.12 & 2.052 & 0.128 & 0.041 \\
\hline 39.0 & 0.45 & 0.67 & 0.31 & 11.9 & 2.106 & 0.122 & 0.037 \\
\hline 40.0 & 0.42 & 0.59 & 0.25 & 9.98 & 2.160 & 0.115 & 0.029 \\
\hline 41.0 & 0.41 & 0.56 & 0.23 & 9.38 & 2.214 & 0.109 & 0.025 \\
\hline 42.0 & 0.37 & 0.57 & 0.21 & 8.74 & 2.268 & 0.104 & 0.022 \\
\hline 43.0 & 0.34 & 0.41 & 0.14 & 5.96 & 2.322 & 0.098 & 0.014 \\
\hline 44.0 & 0.33 & 0.49 & 0.16 & 7.02 & 2.376 & 0.093 & 0.015 \\
\hline 45.0 & 0.30 & 0.49 & 0.15 & 6.55 & 2.430 & 0.088 & 0.013 \\
\hline 46.0 & 0.26 & 0.29 & 0.08 & 3.51 & 2.484 & 0.083 & 0.006 \\
\hline 47.0 & 0.23 & 0.24 & 0.06 & 2.61 & 2.538 & 0.079 & 0.004 \\
\hline 48.0 & 0.21 & 0.40 & 0.08 & 3.99 & 2.592 & 0.075 & 0.006 \\
\hline 49.0 & 0.17 & 0.21 & 0.03 & 1.70 & 2.646 & 0.071 & 0.002 \\
\hline 50.0 & 0.15 & 0.18 & 0.03 & 1.39 & 2.700 & 0.067 & 0.002 \\
\hline 51.0 & 0.13 & 0.27 & 0.03 & 1.77 & 2.754 & 0.064 & 0.002 \\
\hline 52.0 & 0.09 & 0.07 & 0.01 & 0.36 & 2.808 & 0.060 & 0.000 \\
\hline 53.0 & 0.06 & 0.00 & 0.00 & 0.00 & 2.862 & 0.057 & 0.000 \\
\hline 54.0 & 0.04 & 0.35 & 0.01 & 0.75 & 2.916 & 0.054 & 0.001 \\
\hline 55.0 & 0.007 & 0.00 & 0.00 & 0.00 & 2.970 & 0.051 & 0.000 \\
\hline & & & & & & & 1.006 \\
\hline
\end{tabular}

utilization of Geomydoecus oreogonus, a parasite of Thomomys bottae. O ecologia, 15: 287-304.

Saxena, A.K., Kumar S., Gupta N., and Singh, R. (2007). Intrinsic rate of natural increase of poultry fluff louse Goniocotes gallinae (De Geer, 1778) (Isochnocera,
Phthiraptera, Insecta). Zool. Sci., 24: 327-330.

Saxena, A.K., Gupta N., Kumar S., Khan V., Arya G., and Saxena S. (2009). Intrinsic rate of natural increase of five ischnoceran lice (Phthiraptera: Insecta). E ntomol. News, 120 (4): 385-391. 